\title{
Determination of Some in vitro Growth Requirements of Bacteroides nodosus
}

\author{
By T. M. SKERMAN \\ Wallaceville Animal Research Centre, \\ Research Division, Ministry of Agriculture and Fisheries, \\ Upper Hutt, New Zealand
}

(Received 21 August 1974; revised 30 September 1974)

\section{SUMMARY}

Physical and nutritional factors required for growth of Bacteroides nodosus isolates from ovine foot-rot lesions were examined. Simplified anaerobic culture techniques were devised utilizing a fully soluble, autoclavable, liquid medium (TAS) which contained proteose-peptone, yeast and meat extracts and certain other essential compounds required to promote prompt and serially transferrable growth of cultures from small inocula. The latter included Trypticase, arginine, a reducing agent (most suitably thioglycollic acid) and $\mathrm{CO}_{2}$; serine and $\mathrm{Mg}^{2+}$ markedly increased growth yields. Trypticase could not be replaced by a commercial preparation of acid-hydrolysed casein; other forms of hydrolysed proteins gave delayed and inconsistent growth. Maximum growth of cultures required concentrations of 0.02 to $0.05 \mathrm{M}$-arginine, which could not be replaced by glutamic acid, citrulline or ornithine. Exogenous carbohydrate compounds were not required.

The temperature range for optimum growth of cultures was 37 to $39{ }^{\circ} \mathrm{C}$, and anaerobic culture conditions were essential for growth and the production of $B$. nodosus organisms of normal morphology. Solidified TAS media for the isolation and maintenance of $B$. nodosus cultures were also devised.

\section{INTRODUCTION}

Bacteroides nodosus (Fusiformis nodosus), a Gram-negative, non-sporeforming anaerobe, has been recognized as the principal causative agent of foot-rot in sheep, a chronic disease that develops as a mixed bacterial infection of basal epidermal layers of the hoof (Beveridge, I94I; Egerton, Roberts \& Parsonson, I969). As complex methods are required to cultivate strains in vitro, little biochemical study of this organism has been attempted.

Originally, Beveridge (I94I) used a special agar medium containing horse serum for isolating and maintaining cultures, but not all batches of serum were satisfactory and growth was poor in a liquid medium of similar composition. Subsequent attempts to isolate $B$. nodosus by this method were unsuccessful (Beveridge, 1956; MacKenzie, 1956; Thomas, 1958); however, Thomas (1958) eventually obtained consistent growth of cultures on a serum-free agar medium supplemented with finely ground horn from sheep's hooves. A liquid medium incorporating a reducing agent, acid-hydrolysed horn or wool, and auto-digested pancreas or trypsin was also claimed to support significant growth of cultures in 3 to 5 days under nitrogen (Thomas, 1963).

Modifications of Thomas's media include enrichment with yeast and liver extracts, bovine blood, amino acids and various protein digests (Parsonson, Egerton \& Roberts, 1967; Marsh \& Claus, 1970; Egerton, 1974), and the combining of autoclaved extracts 
of hoof and of trypsin in a liquid medium (Roberts, 1967) and in a biphasic medium (Egerton \& Burrell, 1970). These culture milieux portrayed B. nodosus as a fastidious heterotroph, seemingly uniquely adapted for localized growth in hoof epidermal tissue. However, Walker, Short, Thomson \& Roberts (1973) reported that two strains of $B$. nodosus thrived in a comparatively simple medium of peptone and yeast extract, although consecutive cultures of these organisms evidently required large inocula $(10 \%, \mathrm{v} / \mathrm{v})$ to produce the bacterial yields claimed.

Because a physiological characterization of $B$. nodosus strains was contemplated, autoclavable, non-precipitating media yielding prompt and reproducible growth were desired. Furthermore, since $B$. nodosus adjuvant vaccines have prophylactic and therapeutic effects on ovine foot-rot (Egerton \& Burrell, 1970), potentially large-scale methods were required for producing cultures of high biomass concentration and immunogenicity. This paper describes an investigation of various growth determinants of $B$. nodosus leading to the derivation of simplified media that support improved growth of serially transferred, virulent cultures from small inocula. A description of the liquid medium developed has been published previously in the industrial patent literature (Skerman, 1972).

\section{METHODS}

Organisms. Preliminary experiments were carried out with $B$. nodosus strains isolated on hoof agar (Thomas, I958). Cultures were also supplied by J. R. Egerton, McMaster Laboratory, C.S.I.R.O., Sydney, Australia. Fresh isolates, obtained by using modified media, were included in later experiments and were used to verify previous results. All strains were conserved by freeze-drying bacteria harvested from agar cultures. Stock cultures, subcultured weekly, were grown on agar for 4 to 5 days and then stored under hydrogen at room temperature for up to 14 days.

Medium constituents. Proteose-peptone, trypsin I:250, Bacto-Casitone, Bacto-Tryptone Bacto-Casamino acids, Bacto-Oxgall and Bacto-yeast extract were from Difco, 'LabLemco' beef extract, liver digest and sodium thioglycollate were from Oxo Ltd, London; Trypticase, and the peptones Lactalysate, Thiotone, Phytone, Gelysate and Myosate, were from BBL Division of Bioquest, Becton, Dickinson and Co., Maryland, U.S.A.; amino acids, haemin, reduced glutathione, menadione, dithiothreitol and thioglycollic acid (95\% aqueous) were from Sigma; sodium formaldehyde sulphoxylate and all inorganic chemicals used were from BDH; agar was supplied by Davis Gelatin (New Zealand) Ltd, Christchurch, New Zealand.

Carbon dioxide, nitrogen and $\mathrm{CO}_{2}+\mathrm{N}_{2}$ gas mixtures were passed through a deoxygenating column of heated copper turnings before use (Moore, 1966).

Hoof powder was prepared as outlined by Thomas (1958). Acid or alkaline hydrolysis of $200 \mathrm{mg}$ quantities of hoof powder was carried out in sealed ampoules as described by Brenner, Niederwieser \& Pataki (1965). Hoof powder diffusate was obtained by dialysing a suspension of $2 \mathrm{~g}$ powdered hoof in $20 \mathrm{ml}$ water against $80 \mathrm{ml}$ distilled water for 7 days at $4{ }^{\circ} \mathrm{C}$.

Aqueous extracts of trypsin, hoof powder, and heat-killed B. nodosus harvested from broth cultures were each prepared by autoclaving I $\mathrm{g}$ dry wt in $100 \mathrm{ml}$ distilled water at I2I ${ }^{\circ} \mathrm{C}$ for $10 \mathrm{~min}$ and removing the insoluble components by filtration.

Sheep rumen fluid was clarified by centrifugation (Hobson, 1969), and ovine pancreas was autolysed at $4{ }^{\circ} \mathrm{C}$ for 3 days as described by Thomas (I963).

Quantities of all ingredients used are given as their final concentrations in media. 
Preparation of solidified media. The hoof agar medium described by Parsonson et al. ( 1967 ) was used. The basal portion contained (g/I00 $\mathrm{ml}$ water): proteose-peptone, 0.5 ; Lab-lemco, 0.5 ; yeast extract, 0.2 ; agar, $\mathrm{I} \cdot 5 ; \mathrm{pH} 7.6$. The complete medium contained, in addition, $2 \mathrm{~g}$ powdered hoof; this was replaced in experimental media by other supplements, most of which were added to the basal medium before autoclaving.

Plates were poured in $9 \mathrm{~cm}$ glass Petri dishes from $20 \mathrm{ml}$ volumes of sterile, molten medium, and after setting were placed, opened and inverted, in a $37^{\circ} \mathrm{C}$ incubator to dry for $\mathrm{I} 5 \mathrm{~min}$; before use they were stored for at least $\mathrm{I} 2 \mathrm{~h}$ under hydrogen in anaerobic jars (Baird \& Tatlock Ltd, Chadwell Heath, Essex), each fitted with two catalyst sachets.

Preparation of liquid media. The following simplification of classical anaerobic techniques devised and reviewed by Hungate ( 1969 ) proved satisfactory for growing $B$. nodosus. Glass bottles $(28 \mathrm{ml})$ containing $\mathrm{I} 0 \mathrm{ml}$ freshly prepared medium were used as culture vessels; they were fitted with perforated metal screw caps having liners of $3 \mathrm{~mm}$ thick rubber. The caps were loosely screwed on before sterilization of the medium by autoclaving. After the autoclave chamber had returned to atmospheric pressure, bottles were removed immediately and the caps tightened. A partial vacuum developed within each bottle as it cooled to room temperature, when deoxygenated $\mathrm{CO}_{2}$ or $\mathrm{N}_{2}$ was introduced from the gas line through a sterile 22-gauge hypodermic needle plunged through the liner. Sterility of the gas was ensured by attaching a short length of glass tubing plugged with cotton wool to the base of the needle as a filter, both needle and filter having been autoclaved together before attachment to the gas line. Thereafter, the needle was sterilized by flaming. Gas was allowed to flow into the bottle until a slight positive pressure was registered by an in-line manometer when the needle was withdrawn. Inoculum and sterile heat-labile medium constituents were injected into the culture bottles with sterile syringes bearing 26-gauge needles. This technique was suitable for screw-capped bottles up to I 1 in capacity, which could be half to two-thirds filled with medium.

In general, experiments were performed by adding various nutrients anaerobically to a concentrated base and diluting to final volume.

Measurement of growth on solidified media. Growth was assessed by the gross appearance of colonies and was described as good, fair, poor or nil.

Measurement of growth in liquid media. Growth was measured with an EEL Nephelometer (EEL International Ltd, Bayswater, Victoria, Australia) using an OR2 filter. The instrument was set to read 100 against a supplied standard and a sample of uninoculated medium served as the blank. If necessary, cultures were diluted with sterile medium so that turbidities fell within the scale range. EEL readings were calibrated as equivalent direct bacterial counts as measured in a Petroff-Hausser chamber (Arthur H. Thomas Co, Philadelphia, U.S.A.), 50 EEL units being equivalent to $2 \cdot 75 \times 10^{8}$ bacteria $/ \mathrm{ml}$.

Sterilization. Media and heat-stable stock solutions were autoclaved in culture bottles at I $2 \mathrm{I}{ }^{\circ} \mathrm{C}$ for I $5 \mathrm{~min}$, after which the caps were tightened to exclude atmospheric oxygen. Solutions of heat-labile compounds were sterilized by passage through Millipore SwinnexI3 filter units with $0.45 \mu \mathrm{m}$ porosity membranes.

Independently-sterilized medium ingredients were withdrawn from concentrated stock solutions with sterile syringes after first relieving the vacuum within the container by the injection of sterile, oxygen-free $\mathrm{CO}_{2}$ or $\mathrm{N}_{2}$ as described earlier. Required amounts were then injected into the culture bottles of basic medium.

Inoculation and incubation of cultures. Agar plates that had been stored under hydrogen were inoculated in air by streaking and then replaced promptly inside the anaerobic jar 
which was evacuated and filled with a mixture of hydrogen and carbon dioxide $(9: \mathrm{I}, \mathrm{v} / \mathrm{v})$ twice in succession. Incubation was at $37^{\circ} \mathrm{C}$ for up to 5 days.

Freshly-revived lyophilized cultures were grown on agar for $48 \mathrm{~h}$ to provide inocula for experimental liquid media. Growth was harvested in freshly autoclaved $0.15 \mathrm{M}-\mathrm{NaCl}$, washed twice and finally resuspended in saline $(0.85 \% \mathrm{NaCl})$ at a density of approximately $\mathrm{IO}^{8}$ bacteria/ml. Triplicate culture bottles, each containing Io $\mathrm{ml}$ test medium, were then inoculated with $0 . \mathrm{I} \mathrm{ml}$ volumes of this suspension.

When a reproducible liquid maintenance medium had been developed, bottle cultures were initiated with growth from agar plates and thereafter propagated by inoculating fresh medium with $0.0 \mathrm{I}$ vol. culture in the exponential phase of growth. The first or second of such subcultures was used to prepare diluted inocula for the critical assessment of the essential nature of various nutrients and their concentrations supporting optimal growth. Bacteria were concentrated by centrifugation, washed twice and resuspended in autoclaved $0.15 \mathrm{M}-\mathrm{NaCl}$ at a density of $10^{7}$ organisms $/ \mathrm{ml} ; 0.05 \mathrm{ml}$ of this supension was inoculated into each $\mathrm{Io} \mathrm{ml}$ volume of assay medium.

All bottle cultures were incubated at $37^{\circ} \mathrm{C}$ in a water bath and subsequently could be stored at $4{ }^{\circ} \mathrm{C}$ for up to 5 days before subculturing. Each growth experiment was performed with at least three $B$. nodosus strains.

Determination of $\mathrm{CO}_{2}$ requirement. Confirmation of a requirement for $\mathrm{CO}_{2}$ was sought by comparing the growth of liquid cultures in the presence of $\mathrm{NaHCO}_{3}, \mathrm{Na}_{2} \mathrm{CO}_{3}$ or $\mathrm{CO}_{2}$ gas with that under $\mathrm{CO}_{2}$-free conditions. Preparation of a $\mathrm{CO}_{2}$-free medium was accomplished by adjusting the $\mathrm{pH}$ of a solution of all ingredients of the final liquid medium (Table I) except $\mathrm{Na}_{2} \mathrm{CO}_{3}$ to 5.5 with $3 \mathrm{M}-\mathrm{HCl}$ before dispensing. The bottles of medium were then autoclaved for $\mathrm{I}_{5} \mathrm{~min}$ at $\mathrm{I}_{2 \mathrm{I}}{ }^{\circ} \mathrm{C}$, the caps tightened and, after cooling, gassed with nitrogen. Finally, the $\mathrm{pH}$ was readjusted to 6.8 with freshly prepared $2.5 \mathrm{M}-\mathrm{NaOH}$.

\section{RESULTS}

\section{Preliminary experiments with solidified media}

Strains of $B$. nodosus originally isolated on hoof agar survived weekly transfer on the same medium for several months. Cultures incubated under $\mathrm{H}_{2}+\mathrm{CO}_{2}$ for 4 to 5 days resulted in fair growth as flat, colourless colonies and up to $3 \mathrm{~mm}$ in diameter, with irregular margins; as first noted by Beveridge (I94I), they produced a characteristic central pitting of the agar surface (Fig. I). No growth occurred on the basal medium alone, or on the complete medium when plates were incubated in air, in $100 \% \mathrm{H}_{2}$, or in $100 \% \mathrm{CO}_{2}$.

In contrast to hoof powder, equivalent amounts of neutralized acid or alkaline hydrolysates of hoof supported poor or sporadic growth. This situation was somewhat improved when the medium contained a diffusate of a hoof powder suspension added before autoclaving. Streaked cultures also grew on the surface of $5 \times 7 \mathrm{~cm}$ strips of dialysis membrane (Visking) that had been separately sterilized and placed directly upon plates of hoof agar before inoculation.

Further experiments showed that sodium sulphide, sodium thioglycollate or cysteine$\mathrm{HCl}$ was not an effective substitute for hoof powder, but that reduced glutathione (I mM), autoclaved with the basal medium, gave fair but consistent growth. However, growth in the form of more elevated, opaque colonies was substantially increased when the medium was supplemented with trypsin-digested casein (Trypticase, I.5\%, w/v). Acid-hydrolysed casein (Casamino acids, $0.5 \%, \mathrm{w} / \mathrm{v}$ ), on the other hand, was inactive. 


\section{Growth in liquid media}

In preliminary attempts to simulate the Trypticase plating medium with a liquid version dispensed under $\mathrm{CO}_{2}$ or $\mathrm{CO}_{2}+\mathrm{N}_{2}$ mixtures, only faint growth of cultures was obtained after incubation for 3 to 4 days. When supplementary carbohydrates, nitrogen sources, growth factors and metals were screened for growth-promoting activity it was found that either Casamino acids $(5 \mathrm{mg} / \mathrm{ml})$ or a mixture of 20 amino acids $(0 \cdot 2$ to $\mathrm{I} \cdot 0 \mathrm{mg} / \mathrm{ml})$ enhanced growth of cultures incubated for 2 to 3 days. Eventually, this stimulatory effect was traced to arginine and serine, and when the optimal requirement for both amino acids in the Trypticase medium had been established, significant increases in the growth rate and final densities of the bacterial cultures resulted.

Further growth increments were then sought from other supplements to the Trypticasearginine-serine combination in the presence of sodium thioglycollate and $100 \% \mathrm{CO}_{2}$. They included haemin $(5 \mu \mathrm{g} / \mathrm{ml})$, menadione $(0 \cdot 2 \mu \mathrm{g} / \mathrm{ml})$, volatile fatty acids, Krebs-cycle acids, hexoses (all at $0.06 \mathrm{mmol} / \mathrm{ml}$ ), Tween 80 (Atlas Chemical Industries, Inc., U.S.A.; I $\mathrm{mg} / \mathrm{ml}$ ), and $\mathrm{Ca}^{2+}$ and $\mathrm{Mg}^{2+}(0.0 \mathrm{I}$ to $3.0 \mathrm{mg} / \mathrm{ml})$. Additional materials reputedly stimulatory for anaerobic bacteria were ox bile (Beerens \& Castel, 1960), liver digest and yeast extract mixture (Khairat, I966), and isobutyric acid and bicarbonate mixture (Hardy \& Munro, I966). Of these, only magnesium $(0.2 \mathrm{mg} / \mathrm{ml})$, as either the sulphate or chloride salt, increased growth.

\section{Final liquid medium}

The final composition of the Trypticase-arginine-serine (TAS) medium is shown in Table I. Omission of any of the ingredients prevented or impaired growth, and the concentration of each which promoted the highest bacterial densities of three $B$. nodosus strains was assayed independently. Growth yields in TAS medium were not improved by including aqueous extracts of hoof powder, of trypsin or of B. nodosus, or by adding sterile filtrates of liver digest ( 3 to $10 \mathrm{mg} / \mathrm{ml}$ ), ovine pancreas autodigest, bovine blood serum or rumen fluid ( 5 to $10 \%, \mathrm{v} / \mathrm{v}$ ). However, final growth of four strains was slightly increased ( 10 to $20 \%$ ) in the presence of $0.0 \mathrm{I} \mathrm{M}-$ lysine- $\mathrm{HCl}$.

All $B$. nodosus isolates available grew in TAS medium, and of 20 strains examined in detail, all survived ten or more consecutive transfers using as inoculum 0.01 to 0.02 volumes of exponential phase cultures. Even so, there were considerable differences between strains, including recent isolates, in both the time taken to reach maximum population densities after inoculation (range, 16 to $36 \mathrm{~h}$ ) and their maximum growth yields (range, $1 \cdot 75 \times 10^{8}$ to $8.0 \times 10^{8}$ organisms $/ \mathrm{ml}$ ). In general, bacteria grown in liquid media were shorter and wider than those from corresponding agar cultures, although this tendency also varied between strains. Extended incubation of stationary phase cultures was accompanied by a slow decline in culture turbidities, but the extensive lysis of bacteria at the end of the exponential phase recorded by Walker et al. (1973) was not observed.

No culture grown in TAS liquid medium achieved a bacterial density as high as $2 \times 10^{9}$ organisms $/ \mathrm{ml}$, as was reported for two $B$. nodosus strains studied by Walker et al. (I973). The atmospheric and temperature requirements for cultivating these organisms were not disclosed, but the maximum growth of Australian and New Zealand isolates incubated at $37{ }^{\circ} \mathrm{C}$ under $100 \% \mathrm{CO}_{2}$ in a similar medium (3\% Tryptone $+0.5 \%$ yeast extract) did not exceed $1 \cdot 5 \times 10^{8}$ organisms $/ \mathrm{ml}$. Attempts to select mutant organisms with enhanced growth in this medium by prolonging incubation of heavily seeded cultures and subculturing at intervals proved unsuccessful. 


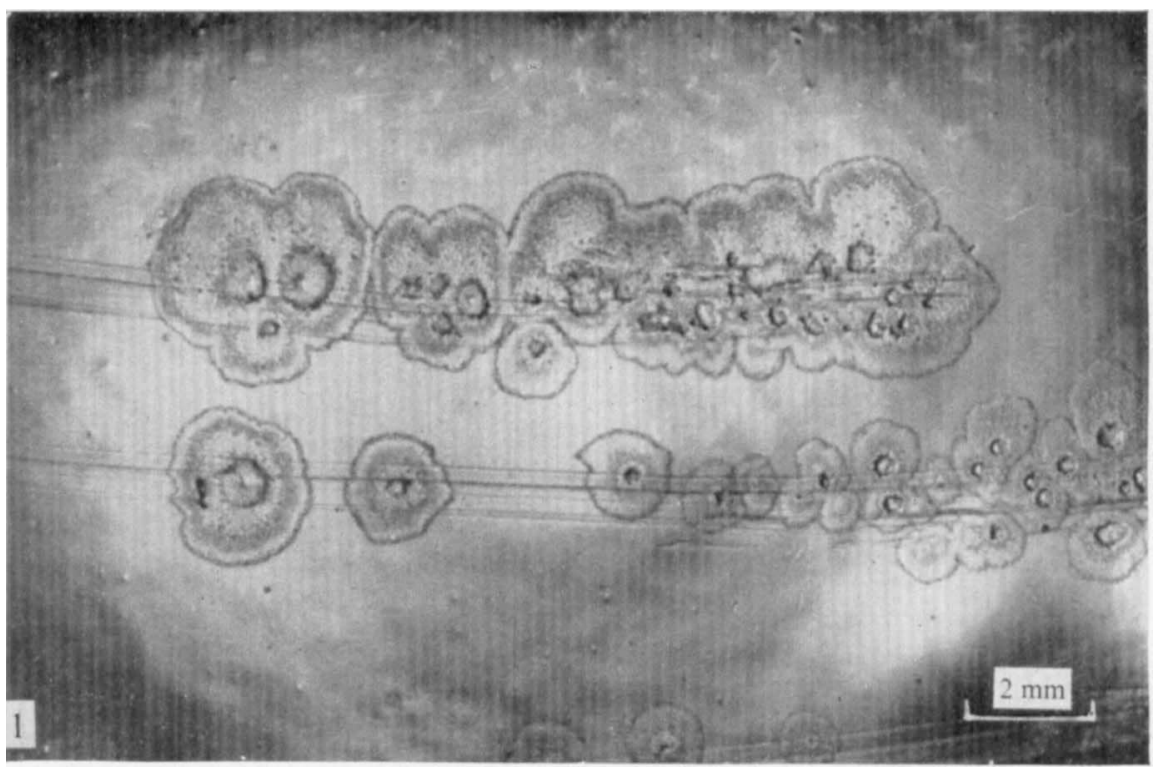

Fig. I. Colonies of B. nodosus grown on hoof agar (Thomas, 1958) for 5 days, showing central etching of the agar surface.
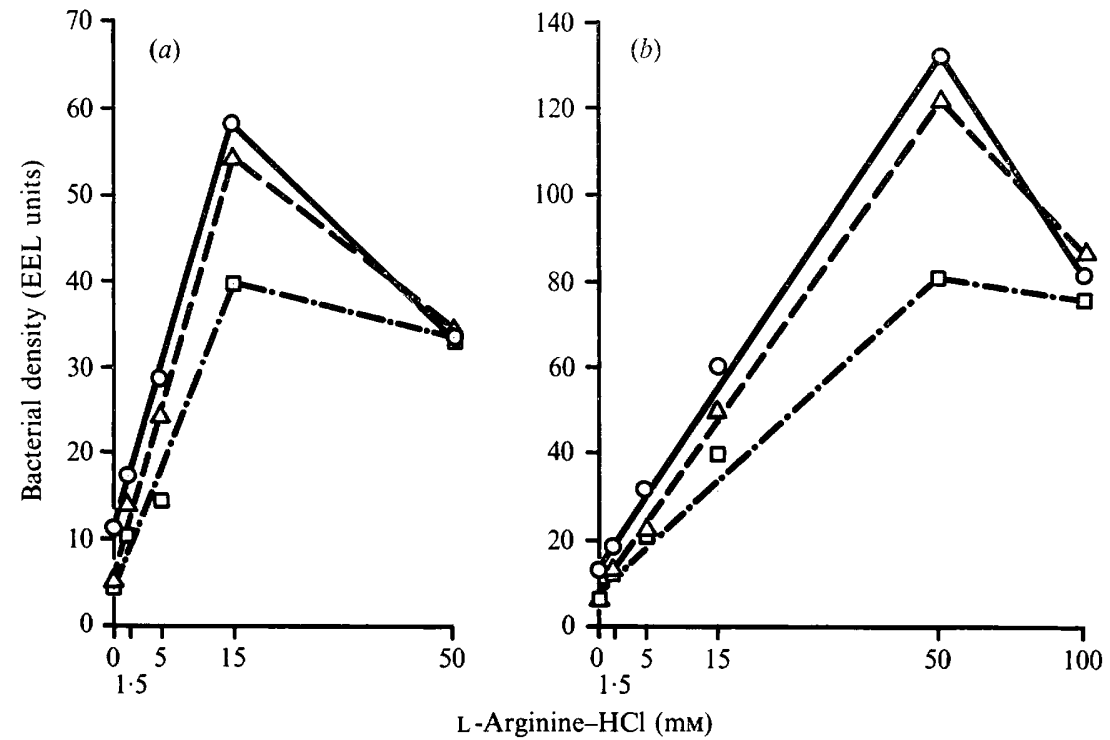

Fig. 2. Growth response of $(a) B$. nodosus strain 4 (McMaster Laboratory strain I3I) and (b) strain 10 as a function of changes in the concentrations of arginine and serine in the medium described in Table I. DL-Serine concentrations: $\square$, nil; $\triangle, 15 \mathrm{mM} ; 0,30 \mathrm{mM}$. 


\section{Table I. Final composition of liquid TAS medium}

A solution in glass-distilled water of all ingredients except $\mathrm{Na}_{2} \mathrm{CO}_{3}$ was adjusted to $\mathrm{pH} 7.0$ with $2.5 \mathrm{M}-\mathrm{NaOH}$ and dispensed in screw-capped culture bottles to about $2 / 3$ capacity. After autoclaving, the bottles were sealed and injected when cool with sterile $\mathrm{Na}_{2} \mathrm{CO}_{3}$ solution and $\mathrm{CO}_{2}$.

$\begin{array}{lc}\text { Trypticase } & \text { Amount/1 } \\ \text { Lab-lemco } & 15.0 \mathrm{~g} \\ \text { Proteose-peptone } & 5.0 \mathrm{~g} \\ \text { Yeast extract } & 5.0 \mathrm{~g} \\ \text { L-Arginine-HCl } & 2.0 \mathrm{~g} \\ \text { DL-Serine } & 5.0 \mathrm{~g} \\ \mathrm{MgSO}_{4} \cdot 7 \mathrm{H}_{2} \mathrm{O} & 1.5 \mathrm{~g} \\ \mathrm{Thioglycollic}^{\prime} \text { acid, } 95 \%(\mathrm{v} / \mathrm{v}) & 2.0 \mathrm{~g} \\ \mathrm{Na}_{2} \mathrm{CO}_{3}, 20 \%(\mathrm{w} / \mathrm{v}) & 0.63 \mathrm{ml}^{*} \\ & \mathrm{I} . \mathrm{ml} \dagger\end{array}$

$\mathrm{pH}$ before autoclaving $7 \cdot 0$

* Reagent stored in screw-capped bottles at $4{ }^{\circ} \mathrm{C}$ under oxygen-free nitrogen and withdrawn by syringe $\dagger$ Sterilized separately by autoclaving.
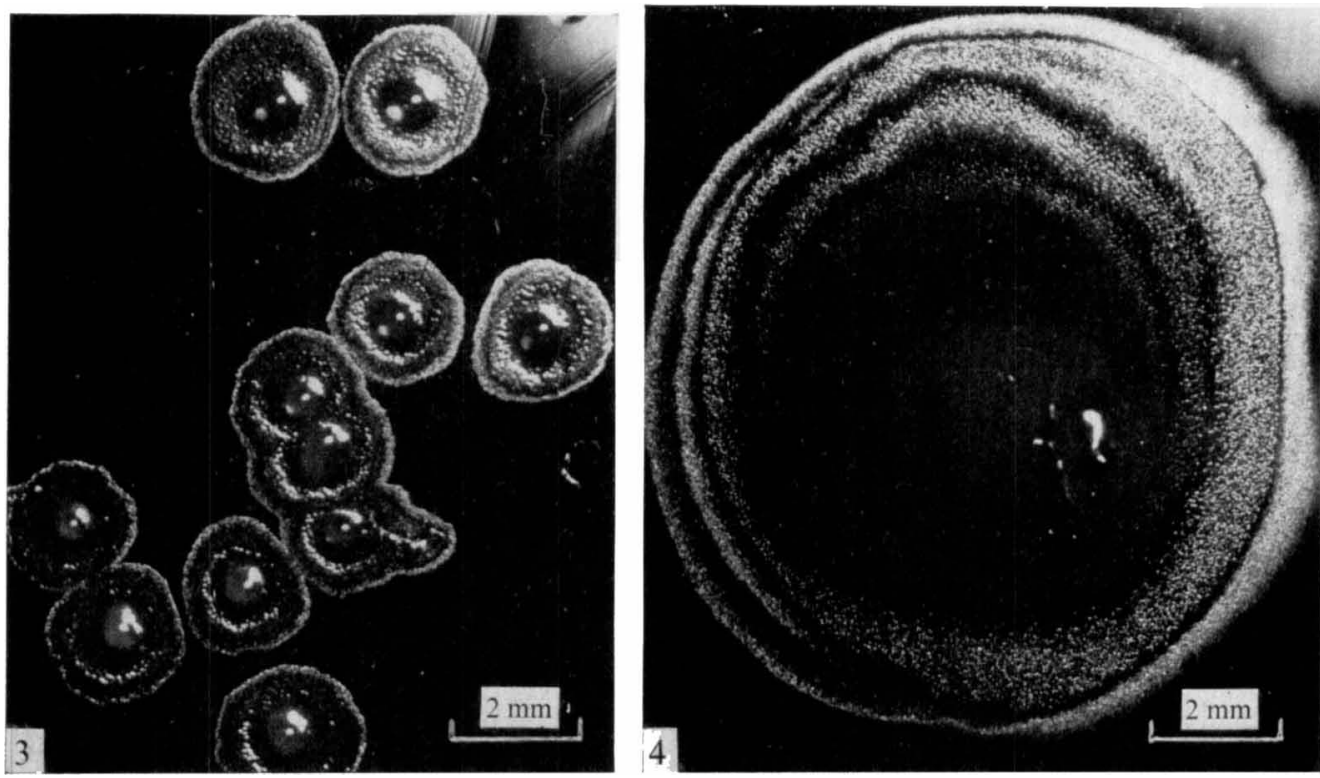

Fig. 3. Typical morphology of colonies from a culture of $B$. nodosus, incubated on TAS agar for 4 days, showing central cone arising from an etched depression in the agar and thin surrounding growth.

Fig. 4. Swarming, non-etching colony from a culture of $B$. nodosus incubated on TAS agar for 4 days, showing thin, spreading growth and lack of central features.

\section{Specific growth requirements}

Arginine and serine. Growth of two strains of B. nodosus in liquid medium, as a function of the concentrations of arginine and serine, is illustrated in Fig. 2. Glutamate, glutamine, citrulline or ornithine could not replace arginine in promoting growth; 0.02 to $0.05 \mathrm{M}-\mathrm{L}-$ arginine- $\mathrm{HCl}$ was optimal for all strains. DL-Serine (approx. I $5 \mathrm{~mm}$ ) was only slightly less effective in stimulating growth than similar concentrations of L-serine.

Protein hydrolysate. Despite the presence of proteose-peptone and meat extract in TAS medium, additional enzyme-hydrolysed protein in the form of Trypticase was necessary to stimulate prompt growth of cultures from small inocula (Table 2). Two different 
Table 2. Comparison of Trypticase with other protein hydrolysates in stimulating growth of three strains of $B$. nodosus

\begin{tabular}{|c|c|c|c|c|c|c|c|c|}
\hline \multirow{3}{*}{$\begin{array}{c}\text { Protein } \\
\text { preparation* }\end{array}$} & \multirow[b]{3}{*}{ Source } & \multirow[b]{3}{*}{ Hydrolysis } & \multicolumn{6}{|c|}{ Growth of B. nodosus $\dagger$ (EEL units) } \\
\hline & & & \multicolumn{2}{|c|}{ Strain 29} & \multicolumn{2}{|c|}{ Strain 37} & \multicolumn{2}{|c|}{ Strain 80} \\
\hline & & & Io h & $40 \mathrm{~h}$ & $20 \mathrm{~h}$ & $40 \mathrm{~h}$ & $20 \mathrm{~h}$ & $40 \mathrm{~h}$ \\
\hline None & 一 & - & 0 & 6 & 0 & 49 & 4 & 40 \\
\hline Trypticase & Casein & Pancreatic & I4 & 67 & 29 & 68 & 74 & 65 \\
\hline Tryptone & Casein & Pancreatic & 0 & 49 & 0 & 69 & 6 & 48 \\
\hline Casitone & Casein & Pancreatic & 0 & 28 & 2 & 64 & 5 & 50 \\
\hline Lactalysate & Lactalbumin & Pancreatic & 0 & 44 & 2 & 44 & 5 & 35 \\
\hline Myosate & Cardiac & Pancreatic & 0 & 0 & 6 & 64 & 6 & 46 \\
\hline Gelysate & Gelatin & Pancreatic & 0 & 4 & 0 & 55 & 4 & 15 \\
\hline Thiotone & Animal & Peptic & 0 & 9 & 6 & 56 & 13 & 53 \\
\hline Phytone & Soya bean & Papaic & 0 & 2 & 3 & 56 & 3 & 42 \\
\hline Liver digest & Ox liver & Papaic & o & 3 & 0 & 47 & 5 & 20 \\
\hline Trypsin & Pancreas & Autolytic & 0 & 0 & 0 & 8 & 4 & 8 \\
\hline Casamino acids & Casein & $\mathrm{HCl}$ & 0 & 10 & 0 & 12 & 3 & 53 \\
\hline
\end{tabular}

* Added to the basal medium to give a final concentration of $10 \mathrm{mg} / \mathrm{ml}$, except for liver digest and Casamino acids, $5 \mathrm{mg} / \mathrm{ml}$, and trypsin autolysate (Thomas, I963), $0 \cdot 1 \mathrm{ml} / \mathrm{ml}$. The basal medium was similar to that described in Table I, with Trypticase omitted.

$\dagger$ Mean of triplicate cultures incubated for 20 and $40 \mathrm{~h}$.

commercial pancreatic digests of casein, Casitone and Tryptone, were not as uniformly effective as Trypticase for all strains, while other forms of hydrolysed protein gave delayed and inconsistent growth. Although the optimum concentrations of Trypticase supporting good rapid growth varied between strains, a level of $15 \mathrm{mg} / \mathrm{ml}$ was eventually adopted for the final medium.

Reducing agents. As shown in Table 3, reducing agents - not necessarily of a thiol type - were essential for the initiation of growth of liquid cultures. Thioglycollate proved the most effective reagent when included in the medium before autoclaving. More reproducible results were obtained by using thioglycollic acid solution than with different batches of sodium thioglycollate.

Carbon dioxide. No growth occurred when the $\mathrm{CO}_{2}$-free medium was inoculated with a dilute suspension of washed bacteria. This was unlikely to have been due to a lack of buffering capacity, because a similar result was obtained when the medium was buffered to $\mathrm{pH} 6.8$ with $0.025 \mathrm{M}-\mathrm{K}_{2} \mathrm{HPO}_{4}-\mathrm{KH}_{2} \mathrm{PO}_{4}$. Growth did occur, however, when this medium was supplemented with $\mathrm{NaHCO}_{3}$, the densest cultures being produced in the presence of $\mathrm{Na}_{2} \mathrm{CO}_{3}$ and a gas phase of 50 to $100 \% \mathrm{CO}_{2}$ (Table 4 ).

Temperature and $\mathrm{pH}$. The optimum growth temperature determined for bottle cultures was 37 to $39{ }^{\circ} \mathrm{C}$. After equilibration with $\mathrm{CO}_{2}$ and $\mathrm{Na}_{2} \mathrm{CO}_{3}$, the $\mathrm{pH}$ of sterile TAS medium in culture bottles was 6.8 to 6.9 . The $\mathrm{pH}$ of cultures at the end of the exponential phase ranged from $7 \cdot$ I to $7 \cdot 3$.

\section{Solidified media}

The composition of maintenance and isolation plating media, complementing that of TAS liquid medium, is shown in Table 5. Since no stimulatory effect by $\mathrm{Mg}^{2+}$ could be demonstrated on the growth of agar cultures, it was omitted from both formulations.

Maintenance medium. Good growth of cultures was obtained on this medium after incubation for 3 to 4 days. A typical individual colony consisted of a central, raised cone 
Table 3. Effects of different reducing agents on growth of three strains of B. nodosus

\begin{tabular}{|c|c|c|c|c|}
\hline \multirow[b]{2}{*}{ Compound $\uparrow$} & \multirow[b]{2}{*}{$\begin{array}{c}\text { Concentration } \\
(\mathrm{mM})\end{array}$} & \multicolumn{3}{|c|}{$\begin{array}{c}\text { Maximum increase in turbidity* (EEL unit } \\
\text { after incubation }\end{array}$} \\
\hline & & $\begin{array}{c}\text { Strain Io } \\
\text { ( } 18 \mathrm{~h} \\
\text { incubation) }\end{array}$ & $\begin{array}{c}\text { Strain } 74 \\
\quad(40 \mathrm{~h} \\
\text { incubation })\end{array}$ & $\begin{array}{l}\text { Strain } 80 \\
(26 \mathrm{~h} \\
\text { incubation })\end{array}$ \\
\hline None & - & I & o & 2 \\
\hline Sodium thioglycollate & IO & 76 & 50 & 49 \\
\hline Sodium thioglycollate & 10 & 42 & 16 & 26 \\
\hline Ascorbic acid & 15 & 65 & $3 \mathrm{I}$ & 49 \\
\hline Cysteine- $\mathrm{HCl}$ & $2 \cdot 5$ & 50 & 59 & 43 \\
\hline Sodium formaldehyde & & & & \\
\hline sulphoxylate & $2 \cdot 0$ & $6 \mathrm{I}$ & 28 & 56 \\
\hline Glutathione (reduced) & $3 \cdot 0$ & 54 & 38 & 23 \\
\hline Dithiothreitol & $1 \cdot 0$ & 4 & 4 & 0 \\
\hline Dithiothreitol + cysteine- $\mathrm{HCl}$ & $I \cdot O+2 \cdot 5$ & 0 & 0 & 0 \\
\hline
\end{tabular}

* Mean for 3 replicate cultures.

$\uparrow$ Added to the autoclaved basal medium as a filter-sterilized solution. The basal medium was similar to that described in Table $\mathrm{I}$, with thioglycollic acid omitted.

t Included in medium before autoclaving.

Table 4. Growth response of three strains of $B$. nodosus to increasing concentrations of $\mathrm{CO}_{2}$

$\mathrm{NaHCO}_{3}$ concn (mg/ml $\mathrm{CO}_{2}$-free basal medium)

0
$0 \cdot 5$
$1 \cdot 0$
$2 \cdot 0$
$5 \cdot 0$
$10 \cdot 0$
0
0
0

$\mathrm{Na}_{2} \mathrm{CO}_{3}, 2 \mathrm{mg} / \mathrm{ml}$
Maximum increase in turbidity* (EEL units) after incubation

Strain $10 \quad$ Strain $29 \quad$ Strain 80
( $18 \mathrm{~h}$ incubation) (20 $\mathrm{h}$ incubation) $(26 \mathrm{~h}$ incubation)

$\begin{array}{rrr}2 & 6 & 0 \\ 4 & 5 & 4 \\ 5 & 7 & 5 \\ 38 & 3 \mathrm{I} & 8 \\ 38 & 21 & 19 \\ 15 & 8 & 30 \\ 48 & 3 & 7 \\ 59 & 57 & 18 \\ 66 & 56 & 29 \\ 82 & 68 & 67\end{array}$

* Mean of 3 replicate cultures.

Table 5. Composition of TAS agar maintenance and isolation media*

\begin{tabular}{|c|c|c|}
\hline Component & $\begin{array}{l}\text { Maintenance medium } \\
\qquad(\mathrm{g} / \mathrm{l})\end{array}$ & $\begin{array}{l}\text { Isolation medium } \dagger \\
(\mathrm{g} / \mathrm{l})\end{array}$ \\
\hline Trypticase & $15 \cdot 0$ & $15 \cdot 0$ \\
\hline Lab-lemco & $5 \cdot 0$ & 5.0 \\
\hline Proteose-peptone & $5 \cdot 0$ & $5 \cdot 0$ \\
\hline Yeast extract & $2 \cdot 0$ & $2 \cdot 0$ \\
\hline $\mathrm{L}-$ Arginine- $\mathrm{HCl}$ & $5 \cdot 0$ & $5 \cdot 0$ \\
\hline DL-Serine & $1 \cdot 5$ & $I \cdot 5$ \\
\hline Washed, packed bovine erythrocytes & - & $(5.0 \mathrm{ml} / \mathrm{l})$ \\
\hline Agar & $15 \cdot 0$ & $22 \cdot 0$ \\
\hline $\mathrm{pH}$ before autoclaving & $7 \cdot 8$ & $8 \cdot 0$ \\
\hline
\end{tabular}

* Cultures incubated under $90 \%(\mathrm{v} / \mathrm{v}) \mathrm{H}_{2}+10 \%(\mathrm{v} / \mathrm{v}) \mathrm{CO}_{2}$.

$\dagger$ A Petri dish containing $40 \mathrm{~g}$ granular $\mathrm{CaCl}_{2}$ was placed inside the anaerobic jar together with inoculated plates. 

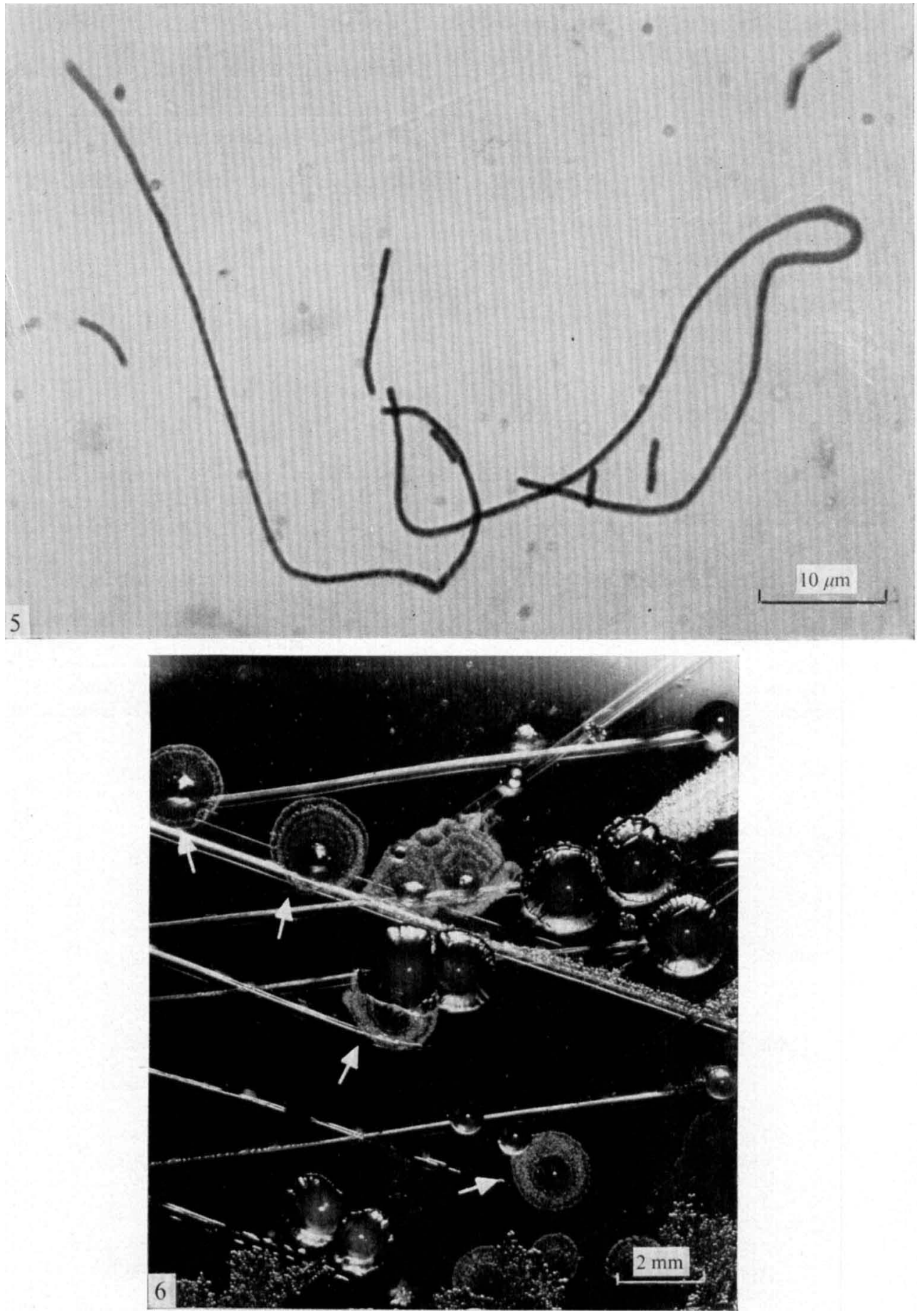

Fig. 5. Filamentous cells from poorly growing $B$. nodosus cultures on agar plates incubated under suboptimally anaerobic conditions (Carbol-fuchsin stain).

Fig. 6. Typical B. nodosus colonies (arrows) growing on TAS isolation agar inoculated directly with necrotic material from an ovine foot-rot lesion. 
(approx. I mm diam.) lying within, and more or less concealing, a circular pit in the agar; beyond this a thin veil of growth extended in the form of a halo to an overall diameter of up to $5 \mathrm{~mm}$ (Fig. 3). Unfixed bacteria from these cultures, examined by phase contrast, were stout, slightly curved rods with rounded ends; their modal dimensions were $6 \cdot 4 \times \mathrm{I} \cdot 0 \mu \mathrm{m}$.

Occasionally, a swarming type of growth appeared on plates in the form of flat colonies up to $22 \mathrm{~mm}$ in diameter; these usually lacked central features and did not etch the agar surface (Fig. 4). Many strains, particularly after repeated subculturing, displayed this swarming phenomenon, which appeared to be associated with a higher than usual degree of hydration of the agar surface since subsequent subcultures inoculated on plates that had been dried for longer periods yielded colonies of typical appearance.

Excessive drying of agar plates at elevated temperatures immediately before inoculation led to oxidative changes that restricted growth in a similar manner to agar cultures incubated in anaerobic jars containing used catalysts whose effectiveness had declined. Growth under these conditions was limited to clusters of etching, pin-point sized colonies which mainly consisted of atypical, filamentous bacilli up to $80 \mu \mathrm{m}$ long (Fig. 5), suggesting that processes associated with division rather than biosynthesis might be especially dependent upon chemically-reduced medium components. Subculture of this aberrant growth under more favourable conditions yielded $B$. nodosus colonies and organisms of typical morphology.

Isolation medium. The isolation of $B$. nodosus colonies from cultures of infected hoof tissue is greatly impeded by numerous organisms from faecal and environmental sources. Dilution of samples of necrotic material in $0.25 \mathrm{M}$-sucrose before culturing was advocated by Merritt (1960) as a means of controlling growth of these contaminants, particularly motile forms which spread rapidly across the surface of the medium. A similar result was achieved by increasing the concentration of agar and the $\mathrm{pH}$ of the TAS maintenance medium before autoclaving, and by including a dessicant with inoculated plates in the anaerobic jar. These modifications did not alter the appearance of typical $B$. nodosus colonies and since these are more readily distinguished when plates are examined under reflected light (Fig. 6) a suspension of bovine erythrocytes was also included in the medium to increase its opacity. As undiluted samples could be inoculated directly on to this medium, a greater number of $B$. nodosus isolates could be recovered from each primary isolation plate.

\section{DISCUSSION}

In view of the tissue specificity of $B$. nodosus infection in vivo (Thomas, 1962; Egerton et al. 1969), the nutritional activity of hoof powder in artificial media devised by Thomas (I958) was a finding of considerable ecological interest. Dialysable peptides, which may be produced from horn by dry grinding (Cohen, 1944), were implicated in the present work as a source of this activity which was also reproduced by enzyme-hydrolysed but not by acid-hydrolysed casein. Further work is required to establish the nature and specificity of the factors concerned.

As keratins in general have a higher arginine content than most proteins (Ward \& Lundgren, I954), hoof powder might also have provided Thomas's media with significant amounts of a nutrient that proved essential for all strains of $B$. nodosus examined. Although arginine cannot be replaced in culture media by citrulline or ornithine, it is rapidly degraded by washed cell suspensions to citrulline, ornithine and ammonia, ornithine being further converted to putrescine and $\mathrm{CO}_{2}$ (Skerman, unpublished data). This evidence, together with the relatively large amount of arginine needed for growth and the apparently low 
carbohydrate demand of the organism, suggests that arginine might constitute a primary energy source for $B$. nodosus and might be catabolized by constitutive arginine deaminase and ornithine transcarbamylase enzymes, with ATP being ultimately generated from carbamyl phosphate.

The freedom of anaerobic TAS media from particulate and heat-precipitable constituents facilitated their preparation by standard autoclaving procedures and the harvesting of bacteria from liquid cultures. The culture techniques described here have been adapted for growing overnight batch cultures in sealed laboratory fermenters of up to 201 capacity, with provision for the anaerobic addition of $\mathrm{CO}_{2}, \mathrm{Na}_{2} \mathrm{CO}_{3}$ and inoculum (o.or volumes). In previous experiments (Skerman \& Cairney, 1972) prompt growth of suitable strains of $B$. nodosus was thus achieved in cultures in which factors associated with virulence and immunogenicity were conserved.

Quantitative growth differences that have been noted among isolates may reflect physiological disparities which have yet to be determined. Detailed taxonomic analysis will also be required to determine whether these are associated with other distinctions between strains, in particular, their virulence (Egerton \& Parsonson, 1969) and their antigenic properties (Egerton, 1974).

The technical assistance of Mr G. Boucher, Miss Elaine O'Connell and Miss Sylvia Bauer is gratefully acknowledged. I also thank $\mathrm{Mr} \mathrm{A}$. Barkus for the photography, Professor J. R. Egerton for Australian isolates of B. nodosus and Dr W. A. Te Punga for helpful comments.

\section{REFERENCES}

Beerens, H. \& CASTel, M. M. (1960). Action de la bile sur la croissance de certaines bactéries anaérobies à gram-négatif. Annales de l'Institut Pasteur 99, 454-456.

Beveridge, W. I. B. (194I). Foot-rot in Sheep: a Transmissible Disease Due to Infection with Fusiformis nodosus (n.sp.). Commonwealth of Australia Council for Scientific and Industrial Research Bulletin No. 140, pp. I-64.

BeVERIDGE, W. I. B. (1956). Foot-rot of sheep. A modern approach to an old problem. Veterinary Record 68, $963-965$.

Brenner, M., Niederwieser, A. \& Pataki, G. (I965). Amino acids and derivatives. In Thin-layer Chromatography. A Laboratory Handbook, pp. 381-432. Edited by E. Stahl. New York and London: Academic Press.

CoHen, H. R. (1944). The effect of dry grinding on the properties of proteins. V. Keratins. Archives of Biochemistry 4, 145-150.

Egerton, J. R. (1974). Significance of Fusiformis nodosus serotypes in resistance of vaccinated sheep to experimental foot-rot. Australian Veterinary Journal 5o, 59-62.

Egerton, J. R. \& BURrelL, D. H. (I970). Prophylactic and therapeutic vaccination against ovine foot-rot. Australian Veterinary Journal 46, 517-522.

Egerton, J. R. \& Parsonson, I. M. (1969). Benign foot-rot-a specific interdigital dermatitis of sheep associated with infection by less proteolytic strains of Fusiformis nodosus. Australian Veterinary Journal 45, 345-349.

Egerton, J. R., Roberts, D. S. \& Parsonson, I. M. (1969). The aetiology and pathogenesis of ovine foot-rot. I. A histological study of the bacterial invasion. Journal of Comparative Pathology 79, 207219.

Hardy, P. H. \& MUNRo, C. O. (1966). Nutritional requirements of anaerobic spirochaetes. I. Demonstration of isobutyrate and bicarbonate as growth factors for a strain of Treponema microdentium. Journal of Bacteriology 91, 27-32.

Hobson, P. N. (1969). Rumen bacteria. In Methods in Microbiology, vol. 3B, pp. 133-149. Edited by J. R. Norris and D. W. Ribbons. London and New York: Academic Press. 
HunGaTe, R. E. (1969). A roll tube method for cultivation of strict anaerobes. In Methods in Microbiology, vol. 3 B, pp. 117-132. Edited by J. R. Norris and D. W. Ribbons. London and New York: Academic Press.

Khatrat, O. (1966). An efficient general-purpose culture medium for aerobes and anaerobes. Canadian Journal of Microbiology 12, 323-331.

MacKenzie, J. (1956). Foot-rot in sheep. Veterinary Record 68, 1060.

Marsh, H. \& Claus, K. D. (1970). The diagnosis of foot-rot in sheep. Cornell Veterinarian 6o, 309-3I 7.

Merritt, G. C. (1960). The isolation of Fusiformis nodosus. Australian Veterinary Journal 36, 388.

MoORE, W. E. C. (1966). Techniques for routine culture of fastidious anaerobes. International Journal of Systematic Bacteriology 16, 173-190.

Parsonson, I. M., Egerton, J. R. \& Roberts, D. S. (1967). Ovine interdigital dermatitis. Journal of Comparative Pathology 77, 309-3 3 .

RoBERTS, D. S. (1967). The pathogenic synergy of Fusiformis necrophorus and Corynebacterium pyogenes. I. Influence of the leucocidal exotoxin of F. necrophorus. British Journal of Experimental Pathology 48, 665-673.

Skerman, T. M. (1972). A nutrient culture medium for Bacteroides nodosus and the preparation of a vaccine against foot-rot in ruminants. New Zealand Inventions Development Authority Patent Application No. 160727. New Zealand Patent Office Journal 61, 899.

Skerman, T. M. \& CaIRNeY, I. M. (I972). Experimental observations on prophylactic and therapeutic vaccination against foot-rot in sheep. New Zealand Veterinary Journal 20, 205-21 I.

Tномаs, J. H. (1958). A simple medium for the isolation and cultivation of Fusiformis nodosus. Australian Veterinary Journal 34, $4 \mathrm{I} \mathrm{I}$.

Thомаs, J. H. (1962). The bacteriology and histopathology of foot-rot in sheep. Australian Journal of Agricultural Research 13, 725-733.

Thomas, J. H. (1963). A liquid medium for the growth of Fusiformis nodosus. Australian Veterinary Journal 39, 434-437.

Walker, P. D., Short, J., Thompson, R. O. \& Roberts, D. S. (I973). The fine structure of Fusiformis nodosus with special reference to the location of antigens associated with immunogenicity. Journal of General Microbiology 77, 35I-36I.

WARD, W. H. \& LUNDGREN, H. P. (1954). The formation, composition, and properties of the keratins. In Advances in Protein Chemistry, vol. 9, pp. 243-297. Edited by M. L. Anson, K. Bailey and J. T. Edsall. New York: Academic Press. 